\title{
The portrayal of single women characters in selected African literary texts
}

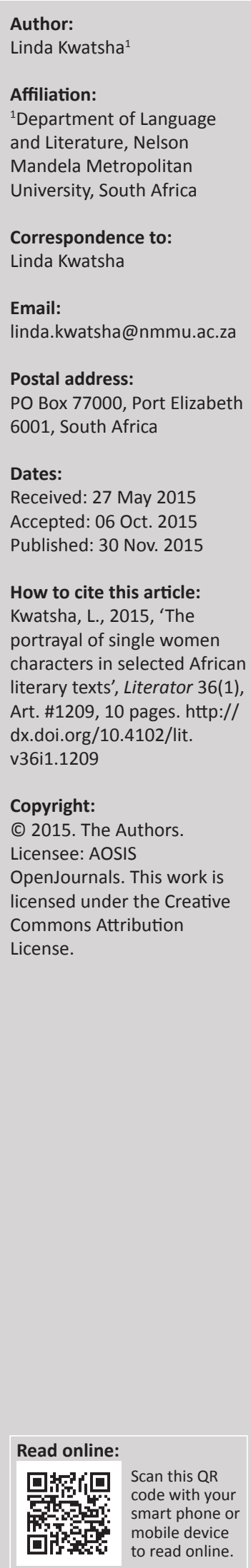

In this article, the portrayal of single women characters in works by a number of African women authors is critically reflected upon. These women are portrayed as strong, resistant, independent and realistic characters, who boldly resist male paternalism and dominance in order to look to the future with courage. Single women characters are presented as independent individuals rather than as kinship appendages. They are portrayed as architects of their own potential happiness rather than as passive receivers of the dictates of patriarchy. The article will also show that women characters account for their own values, rather than subserviently surrender to stereotypical conventions. African women writers portray single women characters as having the professional and economic means to look after themselves. This portrayal of women characters is part of a debate that translates itself to contemporary everyday philosophical social theory.

Die uitbeelding van enkelvroue in enkele literêre tekste uit Afrika. Hierdie artikel ondersoek die uitbeelding van enkelvroue asook hulle pogings om selfstandige status te bereik in werke van 'n aantal vroueskrywers uit Afrika. Dié vroue word uitgebeeld as sterk, onafhanklike en realistiese tipes karakters wat moedig weerstand bied teen manlike paternalisme en oorheersing en wat die toekoms moedig tegemoetgaan. Enkelvroue word uitgebeeld as onafhanklike individue eerder as blote familieskapaanhangsels. Hulle verskyn as karakters wat self hulle potensiële geluk verwesenlik eerder as om bloot die patriargale voorskrifte te aanvaar. Die artikel sal ook aantoon dat die vrouekarakters rekenskap kan gee van hulle eie waardes en nie net inpas by 'n stereotipiese konvensie nie. Die Afrikavroueskrywers beeld enkelvroue uit as sou hulle die nodige professionele en ekonomiese middele hê om vir hulleself te sorg. Hierdie uitbeelding van vrouekarakters is deel van 'n debat wat ook in die hedendaagse filosofiese sienings van die alledaagse samelewing gevoer word.

\section{Introduction}

Today women writers from Africa publish successful and enriching books through which they also become agents of social change. They portray their own backgrounds and their own experience as women creatively, delving deeper into the lives of women in an intimate and authentic manner, whether as feminists or defenders of traditional norms and values. Women writers like Buchi Emecheta, Flora Nwapa, Ama Ata Aidoo, Mariama Bâ and S.A. Dazela epitomise this trend. Works by these authors will be analysed in this article. Although these writers come from different backgrounds, running through their works like a golden thread is the determination to establish that, as human beings, women have rights of their own and should not be discriminated against because they are women. They appreciate and uphold the same values as their male counterparts.

The aim of this article is to investigate how these women writers specifically portray single women characters from a woman's perspective. Common to these works is the portrayal of an inner resilience with which their characters are equipped. Through this inner resilience the characters embody democratic values and become role models and symbols of hope, not only for the empowerment of women but also for their total liberation from all negative perceptions and oppressions. The women writers studied here present stories of day-to-day survival in the experience of characters whose cardinal goal is to live life to the fullest despite its testing crises. In many instances, the stories tell of the empowerment of women in the African context - women who break new ground as leaders in business and in other sectors of the community.

The works studied here share the idea that single women can live fulfilling lives and contribute meaningfully to their future and that of their children without depending on men. Yet, the single 
women characters in these texts are not defiant of their culture. On the contrary, their actions speak of respect for others, but their role is noticeable and not silent. The authors we are going to discuss do not objectify the single women they portray, but present women who because of circumstances or by choice are not married, with the intention not necessarily to send cultural shock waves through the world, but as a demonstration of how women, especially African women, have changed over time. African women have been at the forefront of all human struggles, but by tradition have been relegated to the back seat in their societies.

The trials that single women face in a patriarchal society as depicted in these works can serve as strong indices of the position of women in the broader society. Here the term 'single women' is used to refer to single, divorced, separated and widowed women as well as women who are single and have their own children to take care of. This does not mean that the single woman character does not have an associate or cannot have children, but only that she is not married. Cutrifelli states that:

The new characteristically urban figure of the male-unprotected, husbandless single woman has significantly taken shape: and in the light of the traditional view of celibacy as a social failure, even a crime against society, the consciously deliberate rejection of marriage on the part of an increasing number of urban women appears to be a courageous, indeed daring deed. (cited in Jones \& Palmer 1987:3)

This view should be considered against the unjust discrimination against women in almost all societies and also against the perceived negative perceptions of and attitudes towards women, against all tendencies to place women in a separate category unequal to men by virtue of their biological attributes, oppressing them in their day-to-day life. Ahlstrand (1996) summarises the issue in the following words:

The categories of male and female are stereotyped such that members of the category are assumed to possess certain characteristics by virtue of their biological categories. This results in sexism, the belief that one category, female, is inferior to the other, male. While males are not immune to the negative consequences of sexism, females experience it firsthand since it permeates all levels of our social institutions. (n.p.)

This is especially true of single women, since, as the first quotation states, single womanhood is viewed as an offence in the traditional sphere. As Frank (1987) indicates, until recently most African novels have been written by men, who tended to focus on social, historical and political issues rather than on personal or domestic themes. Even though the novels to be analysed are written by women, the characters in them are defined by their interactions with men, that is, they are someone's daughter, wife or mother, but nonetheless they have a mind of their own and are determined to live life without being enslaved by men.

One can wonder whether this aspiration of black women towards freedom and a higher social status is due to some Western influences or whether the realisation comes from within themselves. The works studied here reveal that the latter is the case. It is the evolution of time that dictates change and attitude.

\section{Background}

On her website, the South Asian feminist writer Sarojini Sahoo is described as writing 'with a greater consciousness of women's bodies, which would create a more honest and appropriate style of openness, fragmentation and nonlinearity' (quoted in the interview with Agarwal 2009). Fernald (2006:5) believes that the negative portrayal of women leads to their being less vocal. The question is whether the women authors do indeed portray their main single women characters with precisely such a greater consciousness and in such a more honest and open style. I argue that they do and that they portray single women characters in their total life experience and do not label them as bad people because of their marital status.

The modern woman's perspective is well articulated by Stegeman (1974, cited in Frank 1987), who contends:

The New Woman represents a theory of personhood where the individual exists as an independent entity rather than in her kinship relations, where she has a responsibility to realize her potential for happiness rather than to accept her role, where she has indefinable value rather than quantitative financial worth, and where she must reason about her own values rather than fit into a stereotyped tradition. (p. 17)

Obviously, Stegeman has studied the history of discrimination against African women under the dictates of tradition and sometimes religion. In this regard, the influence of education and the modern ideas about freedom of choice cannot be overemphasised. Some of the women characters that are discussed in this article are forced into singlehood by circumstances beyond their control, like being abandoned by a husband, left alone to raise children or widowed, while others have taken the route to live without men out of choice. These women find it important to do what makes them happy rather than be forced to comply with values that they cannot accept.

Some people in society still devalue singlehood in women and consider it a personal failure. Stereotypes of single women are couched in pathological terms, such as lack of sexual attractiveness or the inability to form an intimate relationship with another person (O'Connor 1992). Such negative stereotypes devalue the status of women.

Robert (1966) makes a strong case for changing the perception of single mothers; she writes:

Clearly, she is a human being who like all other human beings responds dynamically to her particular life situation, but, she also clearly, chooses one common and specific response, having an out-of-wedlock child. (p. 81)

The underlying principle is that women, irrespective of their background and status, should enjoy freedom of choice like 
all other human beings. That young unmarried girls have children is a common feature in African societies around the continent, despite so-called 'traditional precepts' and church dogma. Marriage is not a condition for child-bearing. Some women deliberately choose to have children outside marriage without fearing that they will be regarded as outcasts in society. In some cases, single women look after children not by choice, but due to circumstances. The idea that a single mother is a woman without a man has become an untenable stereotype.

In an interview with James (1990), Flora Nwapa was asked whether there is any particular message in her work. She responded as follows:

I think the message is, and it has always been, that whatever happens in a woman's life ... marriage is not the end of this world and childlessness is not the end of everything. You must survive one way or the other, and there are a hundred and one other things to make you happy apart from marriage and children. (pp. 114-115)

Some women choose to live without men. They decide against marriage for several reasons. These women see the uniqueness in singlehood because it allows them the freedom to make decisions on their own. To them it is better to stay single and have children than to marry, only to divorce. Rohrbaugh (1981) says:

But women report that the children provide companionship and sense of family. ... These women felt that they made excellent choices for their lives and they are doing what they want at their own pace at their own time. (p. 197)

This view is openly in defiance of certain male ideological constructs and institutional indoctrinations. The manner in which women writers portray single characters is evidence of a trend in the modern way of life that has come to stay. Nonetheless there are some commentators who see single womanhood as a serious problem to society. They state that children suffer as a result of being denied a second parent. Conversely, Cashmore, quoted by Haralambos (1993), argues that it is often preferable for a child to live with one caring parent than with one caring and one uncaring parent, particularly if the parents are constantly quarrelling and the marriage has all but broken down. This is an argument for accepting single motherhood.

The single woman family is sometimes a challenge when a woman has to raise male children without the help of the father figure. Yates (1976) states the following concerning single motherhood:

But no matter how you become a mother, with marriage or without, by birth or adoption, you are raising your children, handling the most demanding, and most rewarding task you ever undertake. You are the primary influence in their lives, their guide in relief and behaviour, their figure of authority and, if you are fortunate enough, their friend. (p. 136)

Yates adds that a single woman makes her own decisions about what she wants to do with her life. She does not do things in order to satisfy other people; the most important thing for her is self-respect. Yates (1976:225) further states that 'a woman should never do anything that will make her uncomfortable with herself'. Yates adds that to choose a man to sleep with is not important; what is important is that anything a woman does is because she wants to do it and not because she is forced to do so by custom. She believes that even if women are staying alone without husbands or partners that does not make them fools. They can achieve a lot without the help of men in their lives, even though many people believe that single women families have a higher risk of poverty than families with two parents.

Sometimes children who are raised by a single parent, whether previously married or not, develop a tendency of becoming delinquent, but this is not always the case, because some of them become successful individuals in life. It is as if Jones (1990) is aware of the present situation in black societies, especially, when she writes:

Let your daughters be liberally, classically and usefully educated, let them speak and write their opinions freely, let them read and think like rational creatures, adapt their studies to their strength of intellect to expand their minds. (p. 242)

This is exactly the ideal towards which single mothers aspire. This means that daughters should be raised in the same manner that parents raise their sons. They should not be given a second chance as if they cannot do anything. They should be raised to be able to become independent human beings. Although written about another society at a different time, Chapman's (1993) argument makes sense of the present thinking that education expands the knowledge of females; they become independent thinkers.

\section{Singleness and polygamy}

Jung (1963) introduces an archetype called the self-archetype. This archetype acts as an inner guide, calling the person forward to new experiences and new discoveries. If we fail to confront our self-archetype, we will arrest progress, feel stuck and frustrated and life will become dull and meaningless. Like Jung, Horney (cited in Louw \& Edwards 1993) believes that we develop psychologically throughout our lives. She claims that each person has an authentic self that provides the energy for continued creative development of the healthy personality. Horney argues that people who live according to their real selves experience feelings and thoughts that are natural and spontaneous, make decisions that give life meaning and do not blame others when things go wrong or become critical in a way that undermines the confidence of others.

In Mariama Bâ's novel, entitled So long a letter (1989), Ramatoulaye Fall, a widow with 12 children, writes a letter to her friend Aissatou in which she narrates major events in her life. Her husband, Modou, died of a heart attack four years after he married a second wife. In this letter Ramatoulaye tells the story of her husband abandoning her and taking as a second wife Binetou, who was a schoolgirl and a friend of 
her daughter, Daba. Ramatoulaye becomes true to herself so as to be happy and live a meaningful and progressive life. She accepts her single life and carries on with her children. Though she is abandoned by Modou, she decides to stay in the marriage and not to divorce him. She interprets Modou's decision as an act of betrayal of her trust and a form of rejection of their love.

In many of these novels polygamy is portrayed as one of the customs that force women to live without men. When a husband decides to take a second wife, the first wife leaves the husband and prefers to stay single rather than to share her husband, as can be seen in the case of Ramatoulaye and Aissatou in So long a letter. French (2008:4) writes that African women are seen as mother, as caretakers, and not as providers or as the independent women known in today's society. Ramatoulaye is abandoned by her husband for one of her daughters' schoolmates. Ramatoulaye knows that she cannot compete with a young girl and that she cannot turn back the clock and become young once more, but she accepts herself as she is. She lives by herself and plans her single life ahead of her. By going her own way, Ramatoulaye is unconsciously freeing herself from the traditional custom of polygamy. Pain and anger fill Ramatoulaye's heart because she still loves the husband who abandoned her for a young girl. Ramatoulaye's life without a man is not a chosen freedom as she and her children are abandoned by her husband, but she learns to live with it and she eventually enjoys it. She is given a car by her friend, Aissatou, a symbol of independence and mobility and she assumes control over her own life. She is able to transport herself and her children. Ramatoulaye is educated and she teaches at the university. As a single mother she has to take care of her children as her husband does not give them either emotional or financial support.

Ramatoulaye realises her potential for happiness because she no longer accepts the role her husband dictates. She is able to take care of everything that her husband used to do. She pays the electricity and water bills, replaces the locks and latches of broken doors and even replaces windows herself: "I was surviving - in addition to my former duties, I took over Modou's as well." (Bâ 1989:51)

The author portrays a single woman character who can survive without the help of men. Although she does not want to break the tradition by divorcing her husband and prefers to be separated, she is living life as a single woman who does not have a husband in her life. She shows strength and capability by embracing what is stereotypically viewed as male prerogatives. She accepts and assumes male duties, as is evident in the phrase 'in addition to my former duties'. After she accepts her position in her husband's life, she realises that a woman can perform any job. In some cases, like Ramatoulaye's, women become grateful to their husbands for leaving them because they discover strengths in themselves that were invisible before: 'The more I thought about it, the more grateful I became to Modou for having cut off all contact!' (Bâ 1989:52).
Though she is clothed with the 'stigmatised' identity that made her a single woman and mother, Ramatoulaye is not concerned with how society will regard her singleness as she never chose it herself. Nevertheless, she is disappointed by tradition that she respects. Singleness chose her. That is why she is courageous in overcoming the negative perception of singleness. Later in her life, she is able to view her singleness as freedom and not as a failure that would destroy her life.

Ramatoulaye is grateful because she was not aware that she would be able to survive without a male figure in her life. She is also indebted to herself because she realises her potential to do things on her own. She is able to know herself better and in the process also realises her capabilities. Her forsaking of tradition affords her the opportunity to discover the ' $\mathrm{I}$ ' who is an independent woman that she never knew existed before because she was always trapped in the world of the 'other' with her husband and the patriarchal dynasty.

Puga, a Mexican woman writer, confirms her real self in her interview with De Beer (1996):

I do believe that I brought to literature a voice of the independent woman, an 'I' who knows she is a woman and does not restrict herself to what is feminine to explore the world and who, at the same time, constitutes the perspective of a woman. (p. 41)

Ramatoulaye discovers an ' $\mathrm{I}$ ' in her and does not restrict herself to only the work done by women. She continues the work that her husband was doing in order to explore every avenue regardless of sex or gender. Astell (cited in Bryson 1999) states:

Feminists argued that women's ability to reason meant that they should be educated equally and they should be able to live independently if they so wish, rather than being forced by economic necessity to become the property of a man through marriage. (p. 10)

Ramatoulaye portrays the ways of an independent woman whose life is fulfilled. She has realised that no obstacle can stand in the way of her success and she is capable of doing anything that she thought she could not do while married to her husband. The portrayal of Ramatoulaye as an independent and fulfilled character contradicts Weedon's (1987:47-48) view that: 'women can never directly exercise the power invested in the position of the father because they do not have a penis'.

In psychoanalysis the 'phallus' (penis) is viewed by Freud as the symbol of social power. It is through their possession of a penis that men are viewed as holding higher status in the community. Although Ramatoulaye does not possess a penis, she can perform the duties that are stereotypically viewed as the domain of men. This reveals that she does not have a fear of loss. She made a conscious decision when she decides to accept her status and be independent of men.

Ramatoulaye's singleness in So long a letter allows her the freedom to make her own decisions. This is why she rejects Dauda's offer to be his second wife. She has experienced 
feelings of being abandoned by a husband and does not want to involve herself in the same situation ever again. Ramatoulaye rejects two other marriage proposals, including Dauda Ding's: 'Dauda Ding, a rich man, a deputy, a doctor, of your own age group, with just one wife. He offers you security, love, and you refuse!' (Bâ 1989:69).

Ramatoulaye feels that she can do anything without her husband and is not influenced by his status. Ramatoulaye releases herself from being a prisoner in her own life. This proves that she does not have problems of self-identity and she does not view marriage as 'a pillar of her identity'. Her rejection of Dauda intensifies that: she is not moved by the man's material possessions and also does not accept the traditional custom of polygamy in her life. She wants a marriage in the Western style: a monogamous marriage.

Aissatou, Ramatoulaye's friend to whom the letter is addressed, also is a woman of strength, hope, courage and goodwill. By giving her friend a car, Aissatou supports her friend and gives her friend the strength to carry on. The car is a symbol of mobility, a symbol of independence. Aissatou tries to instil these traits in her friend Ramatoulaye so that she can understand that her mobility in her life is not vested in Modou's hands. Ramatoulaye does not divorce Modou, as she believes that she might be acting against society by doing so. She also is apprehensive of raising 12 children on her own. Ironically, the anxieties that prevented her from leaving her marriage were in vain, as the tradition she respects so much and the religion she adores disappoint her and leave her a 'single married woman' and mother. To crown it all, what she feared does happen as she has to raise her children alone as her husband does not support her financially. Religion and tradition became her bondage in her marriage.

Aissatou embraces total independence by divorcing her husband because she does not believe in polygamous marriage. As an educated person she rejects both tradition and the patriarchy: 'I am stripping myself of your love, your name. Clothed in my dignity, the only worthy garment, I go my way' (Bâ 1989:32).

Aissatou refuses the idea that men should have social power over women because of the penis they possess. As an educated woman she embraces the Western belief in monogamous marriage. She shows her strength by supporting her friend, an act that in traditional opinion may be viewed as something which is supposed to be done by a man. As a single woman she manages to raise her sons alone. This might also be viewed as against the traditional setup, since boys are believed to belong to their father's homestead.

Aissatou chooses to remain single as she could not accept polygamy. Aissatou's husband, Mawdo, succumbs to his mother's pressure to take a second wife and he marries Nabou, who is his cousin. Although polygamy is a part of the Muslim tradition, Aissatou chooses to break away from that tradition rather than to live in another woman's shadow. She becomes a catalyst for change in her own society.

Looking at the case of the two characters discussed above, polygamy can be seen as giving rise to singleness and independence, but also to uncertainty, disappointment and a new beginning. Ramatoulaye remains oppressed by the cultural ideology as she could not divorce her husband even though he abandoned her. Aissatou is able to say no to traditional culture that is seen as oppressing women and is able to see a future ahead of her. Aissatou stands up against the silence and misery of African women. Although Ramatoulaye remains faithful to her marriage she is able to see that she can survive without a man. Her decision not to divorce her husband is merely formal because her actions and the words that she uses to acknowledge and accept that she is stepping out of the stereotypical female role prove that in her heart and mind she is a single woman.

Efuru, in Flora Nwapa's novel Efuru (1966) does not choose independence, but she is abandoned by her husband, Adizua, for another woman. She calls her mother-in-law and explains to her why the situation has become unbearable:

Mother, I cannot stay anymore. A man said that he had wept for the death that killed his friend, but he did not wish that death to kill him. I cannot wait indefinitely for Adizua; you can bear witness that I have tried my best. I am still young and would wish to marry again. It will be unfair both to you and your son if I begin to encourage men who would like to marry me while still in this house. (Nwapa 1966:88)

Efuru has the courage to leave her marriage, because she knows she is a good trader. As an economically independent woman she has the will, strength and determination to leave her husband and become an independent single woman while waiting for a man to marry her. Even before her husband abandoned her, she was the one who could come up with brilliant ideas about the business. She is an independent-minded and hard-working woman and she knows that she is going to survive at her father's homestead. Efuru is later married for a second time to Gilbert (Eneberi), who eventually again marries a young wife because Efuru cannot bear children. Efuru also chooses to leave this second marriage and be single because her husband was accusing her of adultery: 'I have left Eneberi. ... So here I am. I have ended where I began - in my father's house' (Nwapa 1966:218).

Nwapa challenges an African saying that a woman's home is where her husband is by creating a character like Efuru who, because of marriage problems, ends up at her father's homestead on two occasions, the second time permanently. The character of Efuru disproves Hadjitheodorou's (1999:9) words that the experiences of marriage and womanhood traditionally dominate the lives and identity of women in Africa. The events around Efuru disprove the idea that a woman should have a man by her side in order to succeed and to realise herself. Efuru gains her self-respect and dignity while she is still married. As a wife she is never dependent. 
Efuru's singleness is motivated by the fact that both her marriages fail. Her singleness is not a willed one. She wants to be a wife, which is why she agrees to marry Eneberi, her second husband. Being an economically independent woman, she does not rebel against her traditional custom. She agrees that her husband could take a second wife and also encourages her first husband to pay dowry and perform the marriage customs. As a wife in a traditional society, she also embraces a Western career, that of being an entrepreneur. Two traditions are in conflict in her life as a woman: that of a wife in a polygamous marriage and that of an independent, brave and successful business woman. Although she obeys her traditions, in the end both her husbands fail to see her worth so she ends up as a single woman. Efuru realises herself as a single woman and strives for change and prosperity. She is a symbol of survival, who manages to find a way to escape the traditional patriarchal world by moving to Lagos where her anonymity will be assured and be respected. In the city everyone minds their own business, working for survival. A city is a symbolic space that embraces singleness and gives comfort to single women as they do not feel intimidated by the gatekeepers of tradition.

In Nwapa's novel One is enough (1981), Amaka, like Ramatoulaye and Aissatou in Bâ's So long a letter, packs up her belongings and leaves her husband, Obiora, when he takes a second wife. Amaka makes the decision to leave the traditional society of Onitsha for Lagos, an urban society, where her singleness will be accepted and supported. She decides who will be her partner without having to consult anyone. She feels very satisfied by her actions because she is the one who chooses her 'oppressors' (as viewed by some people who suffer under patriarchal marriage and relationships and forced marriage), not her family or anyone else. She enjoys the independence of owning a threebedroomed house and a car and also having children of her own. Amaka cannot accept the African tradition of polygamy and as such she becomes a symbol of change.

Although her actions might be viewed as immoral, Amaka has different men as partners before she meets Father Izu, with whom she has twin sons. With Izu as a partner, she finds peace and happiness. The economic benefits of this union are only an added advantage. The city environment is a perfect place for Amaka to be independent and to grow as a person.

Here the author portrays a woman who wants the freedom to choose her partners herself. Nfah-Abbenyi (1997:6) avers that 'African critics now generally agree that African women writers offer more dynamic representations of women than the images of subordination often presented by their male counterparts'. This statement supports the argument that the African women writers studied here portray women as strong and independent, thus endorsing an urge for women to be seen as equal to men. Their female characters are portrayed not only in traditionally subordinate roles, but also as characters who are able to build a credible future for themselves. Their successes are measured against multiple predicaments, some of which are caused by men. They set themselves high standards and they live by those standards.

This is exemplified when Amaka in One is enough refuses the church father's proposal to marry her. She expresses herself in unequivocal terms as she declares:

I don't want to be a wife ... a mistress, yes, with a lover, yes of course, but not a wife. There is something in that word that does not suit me. As a wife, I am never free. I am a shadow of myself. As a wife, I am almost impotent. I am in prison, unable to advance in body or soul. Something gets hold of me as a wife and destroys me. When I rid myself of Obiora, things started working for me. I don't want to go back to my "wifely" days. No, I am through with husbands. I said farewell to husbands the first day I came to Lagos. (Nwapa 1981:132)

Here the depth of meaning and the inner resolve of the character can be seen in the repetition of the word 'wife' five times with all the contempt it deserves. Amaka refuses to go back to the submissiveness and powerlessness that she once experienced and this is couched in the following phrases: 'I don't want', 'but not', 'does not suit me', 'I am never free', 'I am a shadow' and 'I am in prison'. All are strong expressions of rejection. Just as Ramatoulaye rejects Dauda's proposal of marriage, Amaka also rejects marriage, preferring to be single and independent of a man's decisions and power.

In the above cases, the authors show that women characters do not see being unmarried as the end of the world, but rather as a beginning of a better world. This demonstrates that they are not dependent on men and that they have faith in their strength as women. Education is also important in women's lives because it gives them strength and independence in life. That is why Ramatoulaye, Aissatou, Efuru and Amaka move from an oppressed to a liberated, autonomous life. Yates (1976:225) states that 'a woman should never do anything that will make her uncomfortable with herself - she has to live herself, no matter who else may be around'.

It should be reiterated that the above women characters are portrayed by the authors to fulfil Yates's idea of women free from male domination and from all negative perceptions of women. They do not want to get married and be unhappy or have their voices ignored because they are women. In these cases the women writers present independent and single women from a woman's point of view. Emecheta and Nwapa created women characters who have the courage to tower above their husbands while single. The authors' single women characters have the freedom to live the life they have chosen.

Emecheta and Nwapa use the traditional environment as a symbol of oppression and dependency. In that environment marriage is the norm and singleness is seen as a calamity. However, the city life is portrayed by these women writers as a representation of new beginnings where independent single women are welcomed, accepted and live without any guilt or shame. It is a symbol of freedom and self-realisation and self-assertion. In a nutshell, one can clearly see that both 
writers are writing against an inflexible institutionalised vision of female characters in fiction.

\section{Singleness and education}

Bryson (1992) argues that for women to be freed from domestic tyranny, they need access to education and employment, so that economic need will not force them into marriage. This is certainly far from the traditionalists' expectation that a woman is brought up in order to marry. Education is seen as an instrument of empowerment.

In The joys of motherhood (1988) by Emecheta, Adaku, Nnaife's younger wife, leaves her husband because she is not happy, as she is always being reminded that she is not able to have male children. She becomes economically independent. She sees education as a tool to save her daughters from being dependent on men. She wants her daughters to be able to survive on their own. Adaku succeeds as a single woman, as she has access to a number of things that her education affords her: intellectual capabilities, skills, experience, a better world view and, of course, some material benefits. Nnaife, her former husband, would not allow her to achieve anything. She distances herself from a life where she will be seen as a second-class citizen and starts a new, fulfilling life for herself. Her singleness is motivated by her state of motherhood as she only gave birth to girls. Her children's gender makes her life as a wife unbearable. So she becomes single and uses a Western weapon, which is education, to give herself power and to empower her girls as well. Her singleness is a statement against discrimination and the patriarchal views that degrade her female children. She succeeds as a trader and she is able to decide on her own what to do with her own life.

Emecheta makes Adaku more successful than NnuEgo, who is still in a patriarchal marriage. She portrays Adaku as a successful woman on her own. NnuEgo is forced to sacrifice her daughters' education because she wants her boys to be educated, unlike Adaku who raises her daughters in the same way that NnuEgo is raising her sons.

Adaku equips her daughters with a powerful weapon, namely education. By giving them education she is giving them independence in life. NnuEgo does not give her daughters a chance to be educated and this may affect her daughters' adult lives. They will become dependent on men, if not their slaves, because from childhood they have never shared the world with equality.

In her interview with James (1990:113), Nwapa states: 'The oppression of women starts in the home. In our homes today, we treat girls differently, and we treat boys as if they are kings'. I have already quoted Jones's (1990:242) views that daughters should receive a full liberal and classical education. In the novel conflicting views on the education of girls are enacted. Adaku observes her co-wife NnuEgo's dependency on her husband and her high regard for male children. NnuEgo wants to satisfy the needs of tradition and of her husband. Adaku realises that, if her girls remain illiterate they will never have the courage to perceive single life as a normal and healthy lifestyle but will keep needing a man for support and survival. She uses her experience of opting out of a marriage because she is ill-treated by her husband for only giving birth to girls as a way to protect her girls. She wants them to see singleness as an appropriate and suitable lifestyle for a woman and she believes that without education that won't be realised.

\section{Singlehood and women abuse}

In Emecheta's novel Double yoke (1982), Nko is involved with two men, Ikot and Ete Kamba. Like Amaka in One is enough, Nko sleeps with Ikot so that she can gain academic success. Ikot takes advantage of her since he knows that she needs to succeed academically. After she has given birth to Ikot's child, she goes back to university and completes her degree. She sees education and her child as more important in her life than men. That is why she decides to reject both men and rather plans to succeed academically and professionally. Ete and Ikot seem only to lust after Nko's body; hence, she decides to free herself from both of them. Ikot uses his position as a professor to force Nko to do him sexual favours in return for getting a degree.

Nko accepts her child, but she does not want the ensuing commitment. That is why she breaks it off with both men, even the father of her child. Emecheta shows that Nko does not link pregnancy with marriage. She wants to have children, but she does not want to be owned by anyone such as in a marriage commitment, especially if this will lead to her being oppressed. Nko extracts herself from a situation where her body would only be used as a currency in exchange for her survival. Her intention to rid herself of male domination is clearly demonstrated by her total rejection of both men. This is symbolic of spiritual cleansing.

Nko sees singleness as a way to escape sexual exploitation and male domination. She does not allow her emotions to be controlled by circumstances and as such she is able to cope with what might have become a personal disaster. Like Debbie in Emecheta's Destination Biafra (1981), Nko becomes a single African mother who sets her sights on academic development.

\section{Robinson (1993) states:}

The influence of feminism has meant that women no longer have to see motherhood, heterosexuality and marriage as the only possible lifestyle. ... Women now feel they have a greater choice as to whether or not to have children or marry, or to opt out of heterosexual relationships altogether. (pp. 222-223)

This view is embodied in the characters I am discussing.

Debbie, in Destination Biafra, wants to live a life where she is valued for her own sake rather than being married off for her parents' financial gain. She rejects marriage because 
she wants to take charge of her own life, rather than seeing herself powerless and submissive to a husband, in-laws and the African tradition. Debbie's unwillingness to enter into an unequal marriage is expressed in the following meditation:

If her parents thought they could advertise her like a fatted cow, they had another thing coming. She would never agree to a marriage like theirs, in which the two partners were never equal. Her father always called the tune. She did not hate him ... she loved both her parents very much. It was just that she did not wish to live a version of their life - to marry a wealthy Nigerian, ride the most expensive cars in the world and be attended to by servants. No, she did not want that. Her own ideas of independence ... had no place in that set-up. She wanted to do something more than child breeding and rearing and being a good passive wife to a man whose ego she would have to boost all her days, while making sure to submerge every impulse that made her a complete human being. (Emecheta 1981:45)

This quotation is an illustration of Bryson's (1992) observation:

Women should be free to follow the career of their choice, and they should not be forced into marriage through economic necessity. If however, they do choose marriage, then this is their career and they should accept the responsibilities that it entails. (p. 56)

This is the kind of independence that Debbie wants. In a marriage situation she would have to abide by the rule of the patriarchal tradition and that is precisely what she is revolting against.

Although Debbie has an affair with one of the army officers, Capt. Alan Grey, a symbol of colonialism in this novel, she does not have marriage in mind. Even being raped by fellow soldiers who only see her as a sex symbol does not weaken her dream of creating a new Nigeria through the army. She sees the idiotic actions of her colleagues as acts of thuggery and weakness. Viewing women as inferior and stereotyping women can in this case be regarded as a weakness and a sickness. It is a dangerous illness that has no remedy. It is only a woman with resolve who could express herself in the way that Debbie does when she rejects Grey's marriage proposal:

No, I am not ready yet to become the wife of an exploiter of my nation. ... I didn't mind you being my male concubine, but Africa will never again stoop to being your wife; to meet you on equal basis, yes, but never again to be your slave. (Emecheta 1981:245)

Debbie's resolve to remain a single woman is fortified and strengthened rather than weakened by the manner in which men treat her in the army. That they regard her as inferior and as a sex object is indicative of male chauvinism and nothing else. Their fear of women is typified by their actions. Alan is no different from his counterparts. In the light of her past experiences at the hands of men, Debbie will not be persuaded to go back to traditional life, which is even more oppressive and protects men.

This resonates well with the view of Snyman and Slabbert (1992:229) that 'females fall victim to males because of men's traditional roles and their status in society'. Debbie chooses to be single to prove her mother wrong. She realises that she herself is a victim of patriarchal circumstances and what she (Debbie) is demonstrating is a reaction to the oppressive life that her mother seems to regard as normal. This is suggestive of the feminist argument that women should be at the forefront of the demand for their own freedom. Breaking free from oppressive circumstances, with all the challenges it presents, is in fact the ultimate goal of every female character in the texts chosen for discussion in this article.

The underlying principle that these texts seem to embody is that a woman's life is not shaped by incidents of abuse or sexual exploitation, but by the choices and changes she makes in line with her character. It is precisely for that reason that Debbie and all those who act like her become symbols of liberation and democracy. These characters' resolutions go against the view of Eckert and McConnell-Ginet (2003) that the force of gender categories makes it impossible for people to move through others' lives in a non-gender-specific way and that it is impossible not to behave in a way that brings out gender behaviour in others.

Taking an example closer to home: in her novel entitled Izono zakho ziya kukujikela (Your sins will turn against you, 1984), Dazela portrays a woman who takes the initiative to divorce her husband because he abuses and ill-treats her. After making an end to the abuse, Nowam, the main character in Dazela's novel, vows never to get married ever again. Her abuse at the hands of her husband, Mpumlo, makes her distrust her in-laws and the society that embraces patriarchy. Her utterances stop just short of declaring traditional marriage a malicious curse. According to her, a woman in marriage is a woman in chains. This view has far-reaching implications for the entire institution of marriage:

Soze babe zizicaka abantwana bam kuba andisafuni mzi wumbi, wanele lo bendikuwo. ... Mama ndixolele, andisayi kurhoxa ekuqhawuleni umtshato. AmaQocwa akhona aze alixhamle ilifa lenu!. [My children will never be slaves because I do not want any marriage, the one I was involved in is enough. ... Mother forgive me, I will not change my mind about divorcing. The Qocwa clan is there, they must take care of your inheritance!] (Dazela 1984:62-63, author's own translation)

McCue (1995) states that women often are victims of physical abuse that ranges from pinches, painful squeezes, punches or shoves to hits or even kicks. Nowam's divorce in response to her abuse is an act of courage that serves as a symbol of independence and happiness in her life. In the passage above Nowam feels that it is preferable for her children to live with one compassionate parent (herself) than to remain in a family setting dominated by her cold-blooded, evil husband, Mpumlo. Her position can be linked to the thoughts of Corbett (1991:13), who indicates that oppressive structures and social relations can relegate females to positions of relative powerlessness and, as a matter of fact, contribute substantially to their susceptibility to further abuse by their male partners. In this case, Nowam (her name means 'of 
myself') is indeed her own person and not anybody else's. The name the author gave her is appropriate as it describes a person determined to fight for her rights. The irony is that the rebellious Nowam is given such a name by her in-laws in the hope that she would return to the patriarchal tradition.

\section{According to Cuddon (1992):}

A notable by product of the whole movement of Feminism and Feminist theory and criticism has been the re-discovery of a hidden tradition of women's writing and the re-discovery and republication and numerous novels and other work by women which had long since sunk more or less without trace, ... except in library catalogues. (p. 341)

Feminist theory has given women authors the opportunity to write and define themselves from a female point of view. It is believed that by taking this bold step, readers will be able to read about female characters who can stand up for themselves without the support of a man.

\section{Singleness and parental influence}

In Emecheta's novel The joys of motherhood, Ona's life as a single woman comes from the powerful way in which her father from early childhood nurtured her in a masculine manner and never gave her the chance to be a weak woman and to be a wife to any man. This affects her profoundly and gives her the emotional strength to remain single. She is fortified by the belief that what a man can do, a woman can do better. As a single woman she has enough strength to cope with all of life's predicaments and even to give Agbadi, her lover, the strength to fight death.

Ona is a woman who has let her personality be moulded by her father. She assumes the role of a man because she was influenced primarily by her father who is her role model. Because of his influence she has no desire to get married to any man. Her father never wanted to see her married, because he never had a son and he wanted her to have sons at his place so that they can become his children. Hence, she and her lover Agbadi agree that if she gives birth to a girl the child will belong to him but if it is a boy it will be her father's. Ona's singleness is embedded in her father's desire to have male children. Even though her father tries to inculcate in her all the principles of good womanhood, his strong manly image outweighs his intentions and as such she lives a single life until the end.

\section{Conclusion}

From the above discussion it is evident that these authors have indeed invented a woman's world. It was invented from a woman's perspective and was indeed not framed by the way that men's language speaks of women, as Cameron (1992:74-75) thought desirable. The discussion in this article has elucidated the role and image of single women in African society and the way in which some single women characters in the selected texts are portrayed as masters of their own fates. It is apparent that the portrayal of single women is not an anti-men campaign, but an attempt by women writers to create a realistic situation where women could be seen as equal to men. This in turn might encourage other writers to invent women's worlds and portray single women characters that are not anti-men but who want to live life to the full without the restrictions of any male-constructed tradition. These women writers are committed to defining the female self in their work as equal to men in opposition to certain views that define women purely from a biological point of view. A woman's biology is important, and is a necessary aspect, but it should not be used as a tool to limit our ideas about women characters in creative writing.

The novels discussed here seem to exemplify Currey's (1987) view:

One of the commitments of the female writer should be to the correction of these false images of the woman in Africa. To do this, she herself must know the reality of the African woman, must know the truth about African women and womanhood. (p. 8)

As women liberate themselves from patriarchal pressures, they will become freer, finding within themselves courage and dignity, and thus will express, the 'true' reality of female experience.

\section{Acknowledgements Competing interests}

The author declares that they have no financial or personal relationships that may have inappropriately influenced them in writing this article.

\section{References}

Agarwal, N.K., 2009, 'Voice of Protest against 'Universal Male Sexual Sadism': an Interview with Sarojini Sahoo', Nebuna: A Journal of Multidisciplinary scholarship 6(2), 1-10.

Ahlstrand, K., 1996, 'Gospel critique of sexism', International Review of Mission 85(336), 47-52. http://dx.doi.org/10.1111/j.1758-6631.1996.tb02731.x

Bâ, M., 1989, So long a letter, Heinemann, London.

Bryson, V., 1992, Feminist political theory: An introduction, Macmillan, London.

Bryson, V., 1999, Feminist debate, Macmillan, London.

Cameron, D., 1992, The feminist critique of language, Routledge, London.

Chapman, J., 1993, Politics, feminism and the reformation of gender, Routledge, London.

Corbett, G., 1991, Gender, Cambridge University Press, Cambridge.

Cuddon, J.A., 1992, Dictionary of literary terms and literary theory, Penguin, Westminster.

Currey, J., 1987, Women in African literature today, Africa World Press, Trenton.

Dazela, S.A., 1984, Izono zakho ziya kukujikela, Shuter \& Shooter, Umtata.

De Beer, G., 1996, Contemporary Mexican women writers, University of Texas Press, Austin.

Eckert, P. \& MacConnell-Ginet, S., 2003, Language and gender, Cambridge University Press, Cambridge.

Emecheta, B., 1981, Destination Biafra, Fontana-Collins, London.

Emecheta, B., 1982, Double yoke, Ogwugwu Afor, London.

Emecheta, B., 1988, The joys of motherhood, Heinemann, Oxford.

Fernald, D., 2006, Patriarchal practices, Oxford University Press, Oxford.

Frank, K., 1987, 'Women without men: The feminist novel in Africa', African Literature Today 15, 14-34.

French, L., 2008, African literature and culture, viewed 28 November 2008, from http://www.mightystudents.com/essay/Africa.Literature.Culture

Hadjitheodorou, F., 1999, 'Women speak: The creative transformation of women in African literature', MA dissertation, University of Pretoria, Pretoria. 
Haralambos, M., 1993, Sociology: Themes and perspectives, Harper-Collins, London. James, A., 1990, In their own voices: African women writers talk, Heinemann, London. Jones, V., 1990, Women in the eighteenth century, Clays Ltd, Devon.

Jones, M. \& Palmer, E., 1987, Women in African literature today, Africa World Press, Trenton.

Jung, C., 1963, In a changing world, Pantheon, New York.

Louw, D.A. \& Edward, D.J.A., 1993, Psychology: An introduction for students in Southern Africa, Lexicon Publishers, Isando.

McCue, M.L., 1995, Domestic violence, Library of Congress Cataloguing in Publication data, CA.

Nfah-Abbenyi, J.M., 1997, Gender in African women's writing: Identity, sexuality, and difference, Indiana University Press, Bloomington.
Nwapa, F., 1966, Efuru, Heinemann, London.

Nwapa, F., 1981, One is enough, Tana Press, Enugu.

O'Connor, P., 1992, Friendship between women: A cultural review, The Guilford Press, New York.

Robert, W., 1966, The unwed mother, Harper \& Row, New York \& London.

Robinson, V., 1993, Thinking feminist: Key concepts in women's studies, The Guilford Press, New York.

Rohrbaugh, J., 1981, Women: Psychology puzzle, Abacus, Aberdeen.

Snyman, L. \& Slabbert, L., 1992, Victimization: Nature and trends, HSRC, Pretoria.

Weedon, C., 1987, Feminist practise and poststructuralist theory, Basil Blackwell, Oxford.

Yates, M., 1976, Coping, Prentice-Hall. 